\title{
Wealth Effects of Dividend Announcements on Bondholders: The Case of Taiwan Bond Market
}

\author{
Ming-Chang Cheng \\ National Chung Cheng University \\ Kai Chen \\ SUNY Oneonta \\ Chien-Chi Lee \\ National Chung Cheng University \\ Chih-Hsun Wu \\ National Chung Cheng University
}

\begin{abstract}
Although bonds play an important role in U.S. capital markets, this financial instrument is less common in the emerging markets. Taiwan is a typical case. In fact, both bond issuances and bond transactions in Taiwan have been declining in the past years. Consistent with the previous studies, this research documents that wealth transfer effects exist between bondholders and stockholders. We hypothesize that this wealth transfer discourages investors from investing in bond markets because companies in Taiwan seem to care less about the interest of bondholders. Using the event study methodology, we examine the price change of bonds and stocks in Taiwan capital market around cash dividend announcements. We find that there are significant abnormal returns before cash dividend announcements from 30 days to 60 days and that there is insignificant price change of bonds during the three-day period around the announcement. Possible explanations of the results include low bond trading volumes, insider trading before announcements, and mixing signaling and wealth transfer effects. Although this study cannot prove that the results are directly related to management holdings, we tend to believe that insider trading somehow matters.
\end{abstract}

Keywords: Taiwan bond market, convertible bond, wealth transfer effect, signaling effect

\section{INTRODUCTION}

Bonds at large are very common financial tools in U.S. capital markets. They help companies operate on better financial leverage options without enduring stock dilution. They also create tax shields for stronger cash flows and better business values. Because of their importance, there have been many empirical studies on bonds, such as bond effects on firm performance and wealth transfers between bondholders and stockholders. In Taiwan, however, bond studies are few and far between, focusing on how bond issues affect stock market. For example, Chang (2010) and Yang et al. (2013) examines the announcement effect 
of private convertible bonds and public convertible bonds. It is quite interesting that while bond studies discussed how bond information affects stock prices, the reverse effect has been ignored. In addition to the fact that bond research is a neglected topic in Taiwan's academia, bond transactions in Taiwan capital market continued to decline drastically in recent years. This is the evidence that bonds are a neglected investment vehicle for Taiwan's investors. Therefore, the aim of this study is to discuss this issue and provide some explanations.

Many previous studies have described a wealth transfer effect between stockholders and bondholders. Our study examines the effects of market reactions around cash dividend events and concentrates on how dividend events affect bond prices. In doing so, we aim to identify the wealth transfer effect between stocks and bonds and the factors that influence abnormal returns. Based on the results of this study, we come up with a possible interpretation for the decline in bond transactions that occurred in Taiwan in recent years. Our results contribute the Taiwan evidence to the literature.

The remainder of this article is organized as follows. The next section describes the data that we use to perform our analysis. The procedure of testing for cointegration and our estimates for the discount rates over time are illustrated in the empirical results. The last section concludes the study.

\section{TAIWAN'S BOND MARKET}

According to the report by Taiwan's Financial Supervisory Commission (FSC), the development of Taiwan's bond market can be classified into three stages.

\section{Stage 1: 1949 to 1990}

The first bond in Taiwan was traced to the Patriotic Bond issued by the government in 1949. During this period, the government used interest rate policy to control the market though the issued volumes were small. Most bonds were held by financial institutions as liquidity reserves, resulting in an inactive secondary bond market. In this period, Taiwan's bond market did not serve an effective function to balance the supply and demand on the loanable fund market.

\section{Stage 2: 1991 to 1999}

Since 1991, the government started to issue more bonds to raise necessary funds for the Six-year National Development Plan, leading to an increasing supply of government bonds in the market. In this stage, the government steadily expanded their financial policy and issued massive bonds to raise funds for public constructions. Private enterprises also began to issue corporate bonds to raise funds. Benefiting from the policy, the bond market went through a structural change and entered a growth period. The bond supply on the market increased significantly over time.

As Gre Tai Securities Market (GTSM), the predecessor of Taipei Exchange, was established in 1994, financial institutions participated in bond markets actively. Beginning in 1997, government bonds were issued in book-entry form, and the Central Bank of the Republic of China (CBC) implemented the realtime gross settlement (RTGS) mechanism for bond transactions. Transaction parties which conducted settlements through the same clearing bank could settle their transactions through the delivery versus payment (DVP) system. These developments simplified government bonds' management and lowered settlement risks for market participants.

\section{Stage 3: 2000 - Present}

In July 2000, GTSM introduced the Electronic Bond Trading System (EBTS), providing bond dealers with an online trading platform which was different from the conventional price negotiations conducted via phones. EBTS significantly improved trading efficiency and thus substantially increased the outright transaction volumes. This marked an important advancement in the history of Taiwan's bond market.

Moreover, the Ministry of Finance, the $\mathrm{CBC}$, and bond market supervisors continued taking actions to improve the issuance, trading, and settlement of bond, such as the primary dealer system, the lending facility for government bonds, the corporate bond and financial debenture trading platform, and the delivery- 
versus-payment (DVP) mechanism, among others. The efficiency of Taiwan's bond market improved substantially and both issuance and trading volume grew markedly. In 2005, the bond trading volume hit a new high, making Taiwan's bond market the second largest in Asia after Japan's.

In recent years, though, as Taiwan's bond market has entered a mature phase, its trading volume has gradually decreased. In addition, financial institutions bought and hoarded a great deal of bonds due to ample funds at hand, which resulted in an insufficient supply of bonds and an imbalance of supply and demand in the market. This has caused distortions of the government bond yield curve. Furthermore, high volatility in the cost of bond borrowing also diminished trading willingness of market participants. All these are crucial factors that have hindered the development of Taiwan's bond market.

We present a few figures to have an overall picture about the evolution of Taiwan's bond market over these three stages. Figure 1 shows the history of Taiwan bond issuances from 1993 to 2016. In 1993, the year when the Gre Tai Securities Market was established, the bond issuance amounted to NT\$785.5 billion, with a lion share in government bonds. As the total bond issuance kept growing over time, so did the corporate bonds. In 2000, the issuance was up to NT\$ 2 trillion, and the component of corporate bonds increased to $25 \%$. Due to the new measures implemented by the government for improvement of bond issuance, trading and settlement, the bond issuance grew extensively. Many different types of bond emerged. At the end of 2016, the bond issuance amounted to NT $\$ 8.43$ trillion, with $66 \%$ in government bonds, $22 \%$ corporate bonds, and $12 \%$ financial bonds.

\section{FIGURE 1}

\section{TAIWAN'S BOND ISSUANCES BY YEAR}

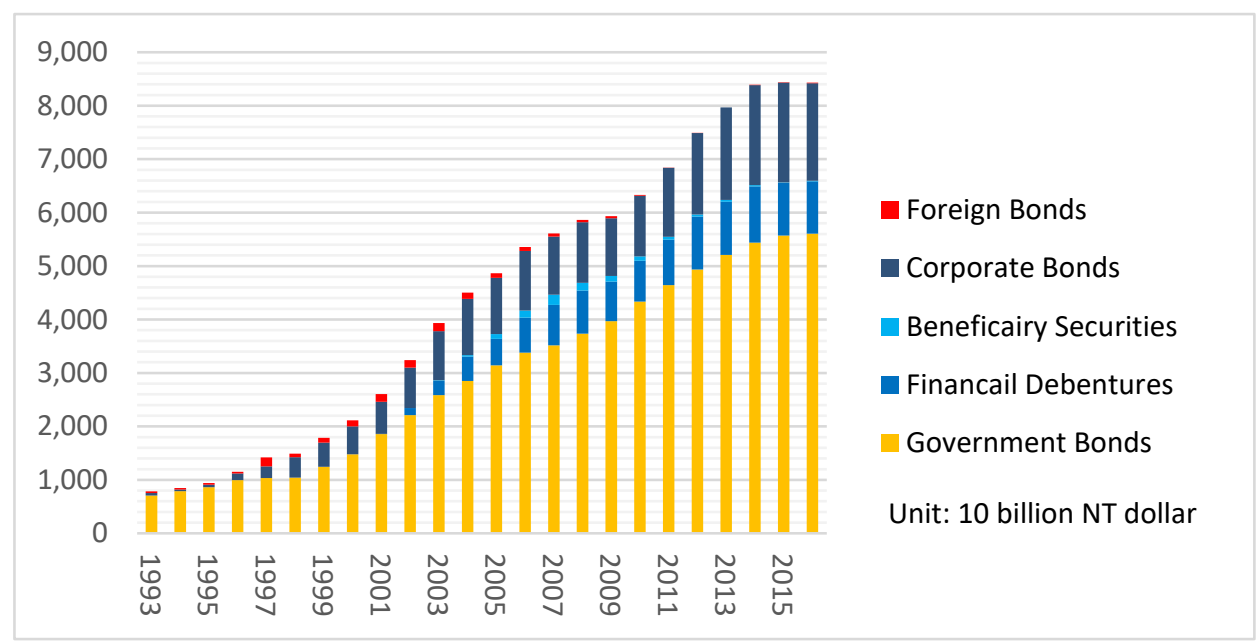

Data source: Taiwan Financial Supervisory Commission

Furthermore, we compare Taiwan's bond issuance and the ratio of the issuance to its GDP with the counterparts in Japan, U.S., China, and Hong Kong. For simplicity, Figures 2 presents the comparison results only in 1998,2006, and 2016. The comparison shows that over our sample period, not only the bond issuance in Taiwan is much lower than in United States and Japan, also the growth in bond issuance in Taiwan is slower than in China and Korea. In terms of the ratio of bond issuance to GDP, Taiwan ranks in the bottom. These results indicate that the bond market in Taiwan plays less important role in economy.

Also, we look at the bond trading volume in Taiwan from 1997, the earliest year getting the data, to 2016. Figure 3 shows that the trade volume grows considerably after the launch of the Electronic Bond Trading System (EBTS) in 2000 and reaches its peak, \$129 trillion, in 2005, which is 1,100\% of Taiwan's GDP that year. Thereafter, the trading volume goes down and the financial tsunami in 2008 speeded up the down trend. In particular, the trade volume of NT\$8.65 trillion in 2008 is only one-fifteenth of the volume in 2005 and $50 \%$ of the concurrent year's GDP. 
FIGURE 2

BOND ISSUANCE VOLUMES AND DIVISION BY GDP



(a) 1998, in billions of U.S. dollar

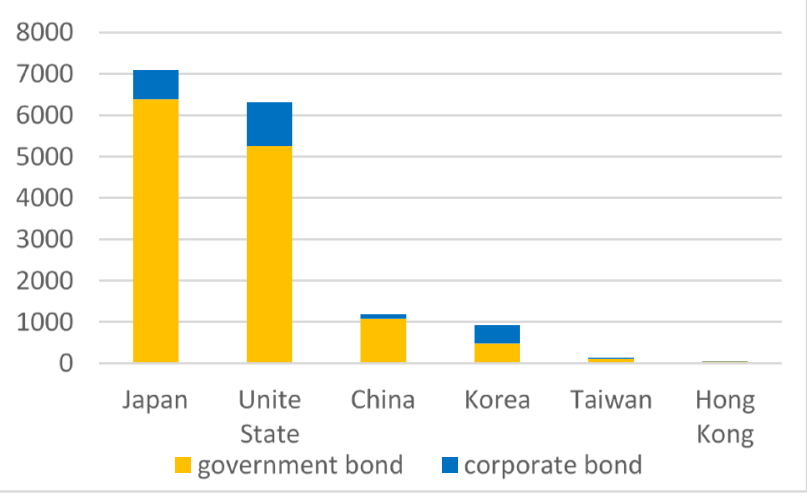

(c) 2006, in billions of U.S. dollar

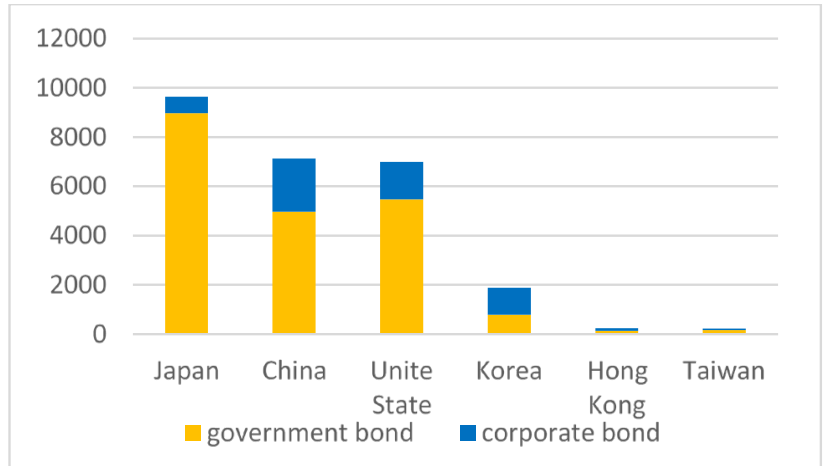

(e) 2016, in billions of U.S. dollar

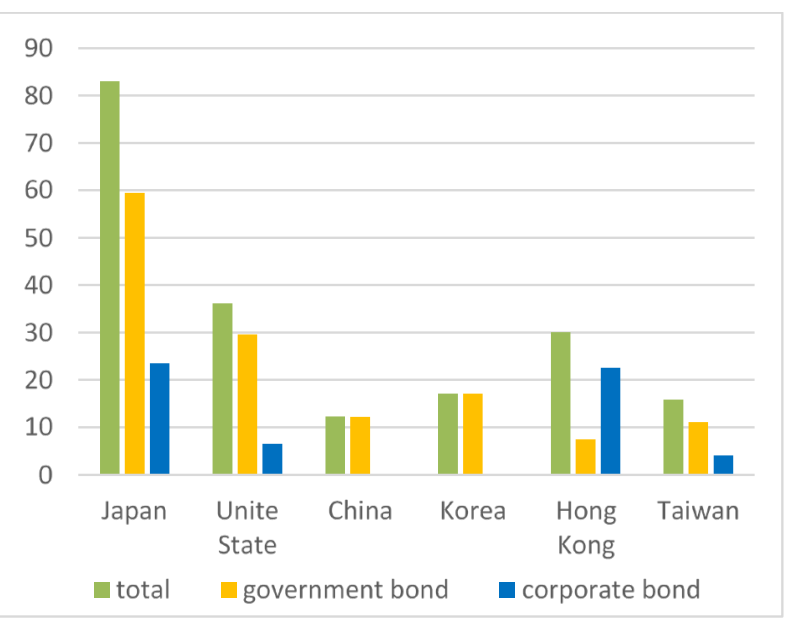

(b) 1998 , in $\%$ of GDP

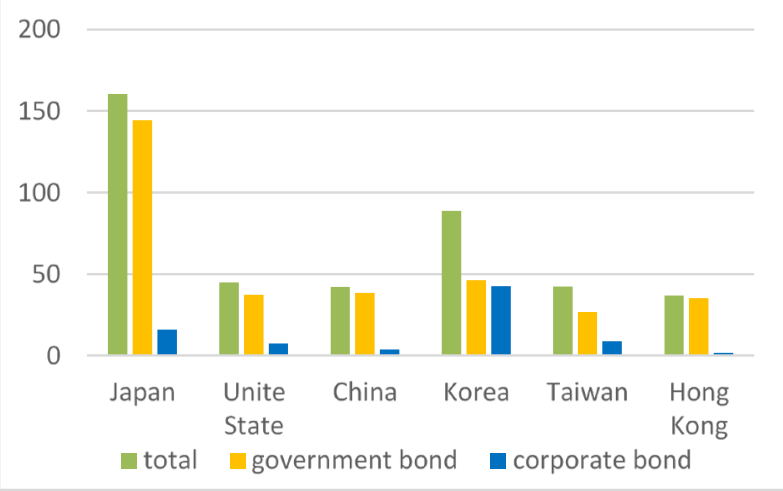

(d) 2006 , in \% of GDP

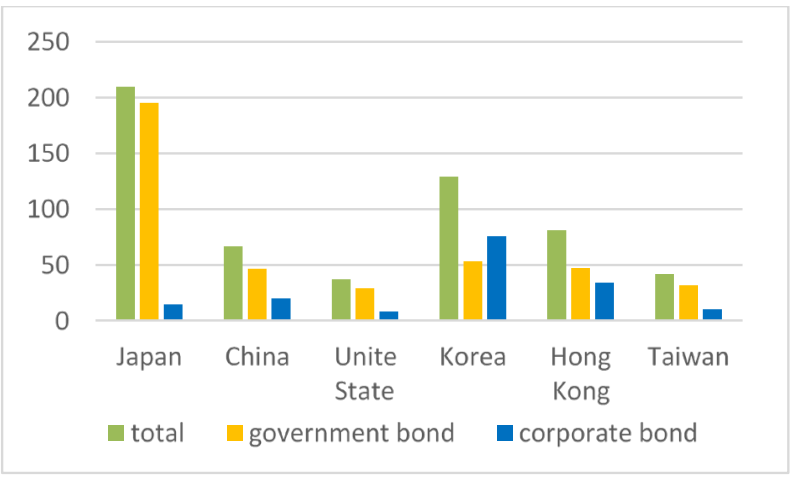

(f) 2016 , in $\%$ of GDP

Data source: Asia-ADB, Taiwan-FSC, US-SIFMA 
We further compare the ratio of the Taiwan's bond trading volume to its GDP with the counterparts in Japan and United States. The comparison in Figure 9 shows that even though this ratio in Taiwan is smaller than in Japan and United States before 2005, difference has become larger and larger since 2006. This result is consistent with the result from Figure 2, support that the bond market in Taiwan plays less important role in economy, especially after 2007.

\section{FIGURE 3 \\ TAIWAN'S BOND TRADING VOLUME BY YEAR}

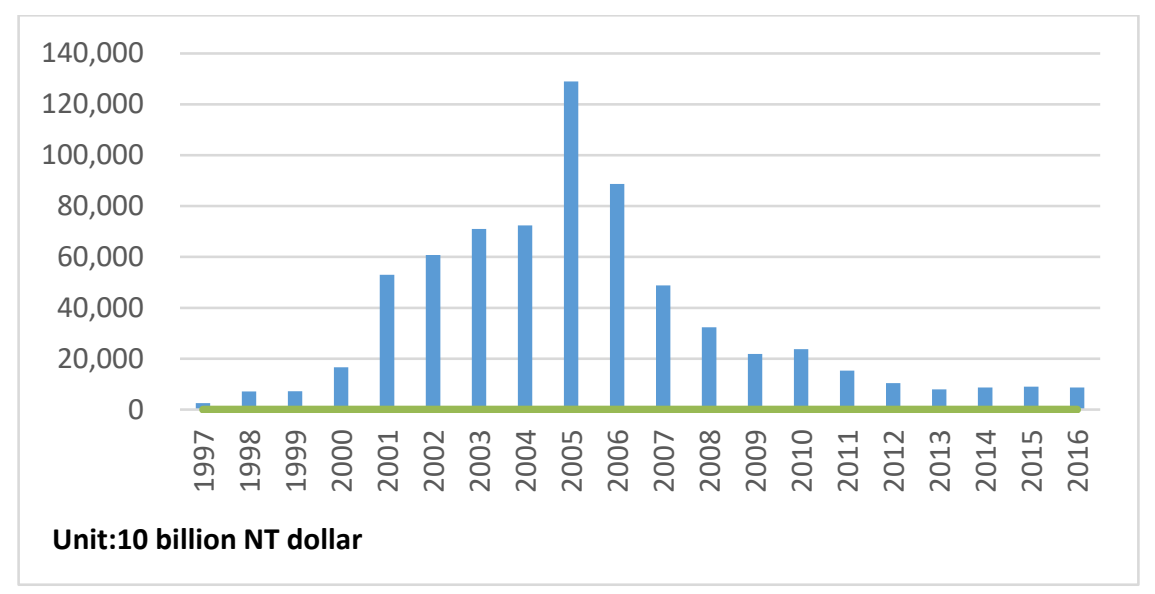

Data source: Taiwan Financial Supervisory Commission

\section{FIGURE 4}

TAIWAN, JAPAN, AND U.S. BOND TRADING VOLUME IN \% OF GDP BY YEAR

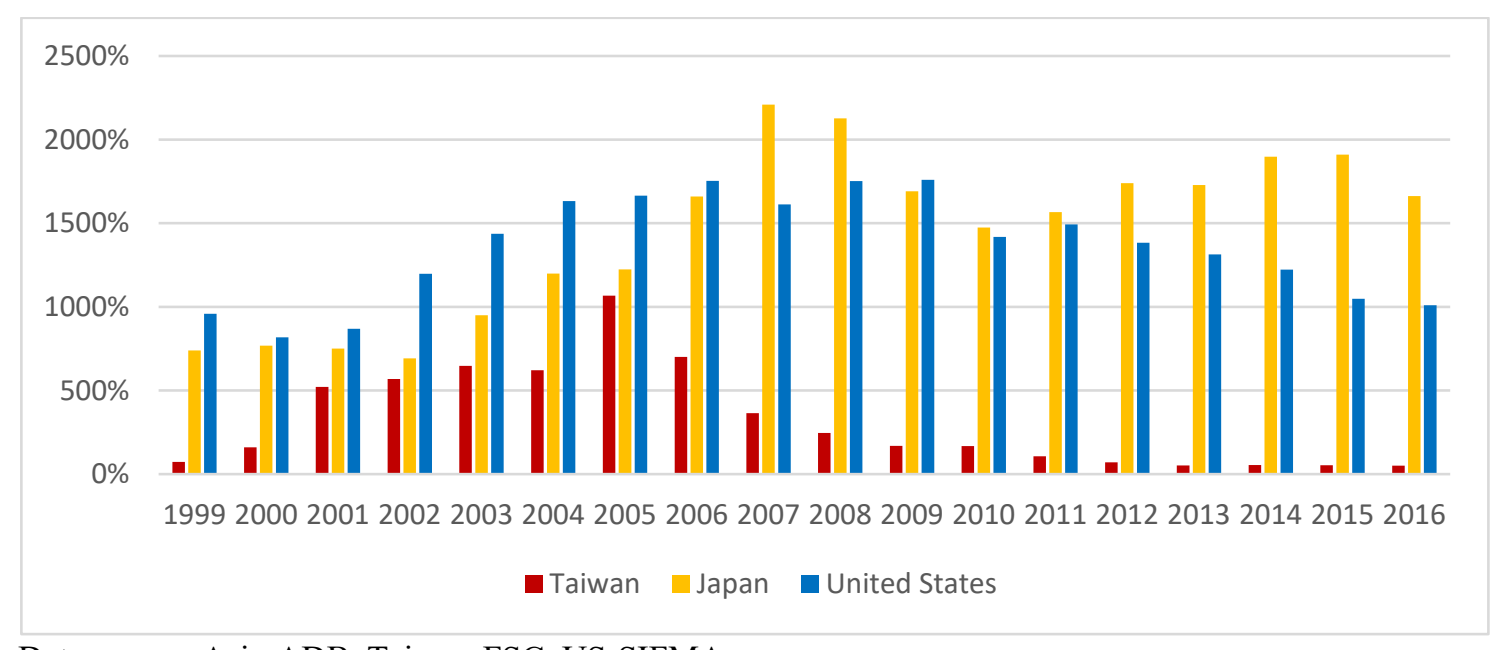

Data source: Asia-ADB, Taiwan-FSC, US-SIFMA

\section{LITERATURE REVIEW}

\section{Efficient Market Hypothesis}

To do an event study, the researchers assume that the market is efficient. If the market is inefficient, it is possible for investors to earn abnormal returns.

Fama (1970) was among the first researchers to develop the efficient-market hypothesis (EMH), which pronounces that stocks are traded at their fair values, making it impossible for investors to either purchase undervalued stocks or sell stocks for inflated prices. There are three variant assumption forms: "weak", 
"semi-strong", and "strong". The weak form of the EMH claims that prices of traded assets (e.g., stocks, bonds, or property) already reflect all past publicly available information. The semi-strong form of the EMH claims that prices reflect all publicly available information and that prices instantly change to reflect new public information. The strong form of the EMH additionally claims that prices instantly reflect hidden "insider" information.

The concept of efficient markets rests largely on the idea of the random walk. The random walk proposes that price changes in the data series today are independent of the data series from yesterday. All subsequent price changes represent departures from previous price changes. This builds largely on the premise that the flow of information is uninterrupted and without costs. Given that all information is immediately reflected in prices, tomorrow's price will change in reaction only to tomorrow's news that is unexpected today. Thus, tomorrow's price must be unpredictable and random. According to the same postulate, the efficient market hypothesis further suggests that investors do not earn abnormal return without taking on an abnormal risk.

Farmer and Lo (1999) believe that an efficient market is not an accident of nature, but a direct outcome of many active participants attempting to profit with their information. However, in modern financial economics, there is a tradeoff between expected returns and risks.

If the expected return on an asset is positive, it may be the reward needed to attract investors to hold the asset and bear the corresponding risk. Indeed, if an investor is sufficiently risk averse, he might gladly pay to avoid holding a security that has unforecastable returns. In such a world, prices do not need to be perfectly random, even if markets are operating efficiently and rationally.

Hadi (2006) points out some reasons that might lead to inefficient market, including: (1) the investors are unable to interpret the new information correctly; (2) the investors have no access to the new information; (3) the transaction cost is an obstruction for free trading; (4) the restriction on short sale; (5) the investors might be misled by the change in accounting principles.

We cannot compare the relative efficiency of markets as opposed to the all-or-nothing notion of absolute efficiency. The profits that accrue to an investment professional need not be a result of market inefficiency but may simply be the fair reward for unusual skill, extraordinary effort, or a breakthrough in financial technology.

\section{Signaling Hypothesis}

Miller and Modigliani (1961) suggest that dividends contain information about the firm's cash flows in the future. They show that in perfect capital markets with no information asymmetry the value of a firm is independent of financing decisions if the production-investment decision is given. Thus, the payment of cash dividends to equity holders is of no consequence to stockholder wealth or firm value.

Miller and Rock (1985) extends the standard finance model and concludes that there are three kinds of decision (dividend/investment/financing) which allow the firm's managers to know more than outside investors about the true state of the firm's earnings.

Healy and Palepu (1988) provide ample supports for the dividend informational role. They focus on a special set of unexpected dividend changes with the strongest element of surprise, which means dividend initiations and omissions are clearly unanticipated among investors. The results suggest that managers attempt to give signals regarding their company's future earnings. Nissim and Ziv (2001) develop a particular model of earnings expectations and find a positive association between current dividend changes and future earnings changes. In general, all these studies support the signal hypothesis.

Additionally, many Taiwanese studies support the signaling hypothesis. Wang (1994) and Chang (1996) find that announcements of dividend contain information about a firm's current and/or future cash flows. Lin \& Pan (1998) and Tsai (1994) examine trading volumes to discuss information of cash dividends and stock dividends, respectively. All these results support the signaling hypothesis.

There has been a large body of literature examining the effect of dividend announcements on stocks. Evidence suggests that dividend increases (decreases) are associated with significant positive (negative) stock price responses. However, evidence on the impact of dividend change announcements on bondholders is mixed and scarce. 
Using the event study, Woolridge (1983) and Handjinicolaou and Kalay (1984) find that bondholders experience positive, though statistically insignificant, abnormal returns from the announcement of dividend increases but respond in a negative and statistically significant fashion to dividend decreases. These two studies discover that abnormal bond returns move in the same direction as abnormal stock returns which is consistent with the signaling hypothesis for the U.S bond market. However, there is no study to support the signaling effect in Taiwan's bond market.

\section{Wealth Transfer Hypothesis}

The signaling hypothesis and the wealth transfer hypothesis are of little difference. Although each of these hypotheses is consistent with a positive stock price reaction to a dividend increase, the predicted bond price reactions are different: signaling hypothesis implies bond prices should increase when dividend increases are announced, whereas the wealth transfer hypothesis implies bond prices would fall.

It is worth noticing that while these two hypotheses have different implications for bond price reactions to dividend changes, they are not mutually exclusive.

The wealth transfer hypothesis, proposed by Galai and Masulis (1976) and others, claim that a conflict between bondholders and shareholders would result in a transfer of wealth from bondholders to shareholders through dividend payments. Dividends can potentially transfer wealth from bondholders to shareholders by increasing default risks of outstanding debts.

Dhillon and Johnson (1994) observe U.S securities market in the 1975 - 1976 period and find a positive price reaction to large dividend increases in the stock market and a negative price reaction in the bond market, which is consistent with the transfer wealth hypothesis. Moreover, they use a large dividenddecrease sample to confirm wealth transfer effect with stock price declines accompanied by positive bond excess returns.

From the perspective of wealth transfer, dividends might harm debt holders as it not only increases the likelihood of defaults, but also lowers the amount of assets that can be used for repayment, should forfeiture once occur. As bondholders are not compensated for the increased riskiness of their claims, they lose wealth when dividends are paid, while shareholders gain.

\section{METHODOLOGY AND DATA}

\section{Model}

This paper employs event study methodology to measure the effect of dividend announcements. The basic idea of the approach is choosing a time window around the event and calculating the rate of the abnormal returns over the window. The purpose is to test whether the rate of the abnormal return is significantly different from zero in the study window and how the rate of the abnormal return is determined. First, we use market model to estimate normal expected returns, then compare them with realized returns and get the difference (abnormal returns). Then, regression method is used to find out which factors affect the abnormal returns.

In Taiwan, most finance research uses TEJ's event study system to calculate abnormal returns. However, that system cannot calculate bond's abnormal returns. Thus, we decide to use market model methodology with SAS system. While some previous studies use bond rating to create raw returns, Taiwan's bond rating is not mature. For that reason, we set Taiex index into the model as the market portfolio.

The market model developed by Sharpe (1963) is widely used in empirical financial research. It states that security returns are a linear function of rate of return on market portfolio. The market model can also be written in mathematical terms as:

$$
\text { Rit }=\alpha i+\beta i \times R m t+\mu i t
$$

where,

$$
\text { Rit }=\text { Return on security } i \text { in period } t \text {, }
$$


$\mathrm{Rmt}=$ Rate of return on market portfolio in period $\mathrm{t}$

$\mu \mathrm{it}=$ Residual term, which is part of security return that cannot be explained by Rmt,

$\alpha \mathrm{i}=\mathrm{E}(\mathrm{Rit})-\beta \mathrm{i}[\mathrm{E}(\mathrm{Rmt})]$, i.e., the estimated intercept of the regression equation,

$\beta i=\operatorname{Cov}(R j t, R m t) / \operatorname{Var}(R m t)$, i.e., the estimated slope of the regression equation.

According to Strong (1992), the market model "results in small variances of abnormal returns (relative to raw returns), and that will result in more powerful statistic test and conformity to standard statistic tests.

\section{Event Data Source}

There are many studies on dividend announcements. Some of them use monthly data while others use daily data. Previous research proves that using monthly returns, particularly in small samples, would lead to a weaker power of tests relative to using daily returns (Brown \&Warner, 1985; Bessembinder et al., 2009).

We use daily data for our analysis. We recognize the event dates of dividend announcements, which are recorded as Declaration Dates in Taiwan Economic Journal (TEJ), and then calculate changes in dividends between current and previous periods. We also gathered specific information about bond characteristics such as secured, rating, accrued interest, and maturities. Stock returns and firm accounting information are drawn from TEJ.

To include the sample, a dividend announcement must satisfy the following criteria: a) the firm's bond data are available in the TEJ during the event windows, b) the firm pays taxable cash dividend in NT dollars in current and previous periods. Since Taiwan's electronic trading system started in 2000, we accordingly have a sample period beginning with January 2000. These sample selection criteria result in a sample of 1,243 dividend announcement observations, with 594 dividend decreases and 649 dividend increases, from January 2000 to December 2016.

Event study calculates the size of the impact of an economic event on the value of the company based on a market model which is estimated under three implicit assumptions: (1) the capital market is efficient; (2) The event is not expected; (3) There are no other events during the event period. In this paper, we use the sample of daily return data of 180 days before the event days to estimate $\alpha \mathrm{i}$ and $\beta \mathrm{i}$ in the market model. We use 180 days as estimation period to avoid the effect of the previous dividend payment on the market model. Most firms in Taiwan pay dividends annually. If the period is longer than half a year, the effect of a dividend announcement would be affected by the previous one.

Table 1 provides descriptive statistics of firm characteristics of the sample. Over the sample period, we observe fewer cash dividend announcements in the earlier years. In 2009, there are only 10 dividend increase announcements but 65 dividend decrease announcements. This might have been caused by the global financial crisis. This argument is supported by the decline in the average of dividends in 2009. Interestingly, we identified a trend of increase in the average of dividend, even in the decrease panel. Though the economy became worse during the financial crisis, the average of dividends was still higher. This means that during the financial crisis, company managers value placing a higher weight on the importance of dividends. As discussed previously, when a company pays more dividends, it may make investors believe that the company will earn more money in the future. 


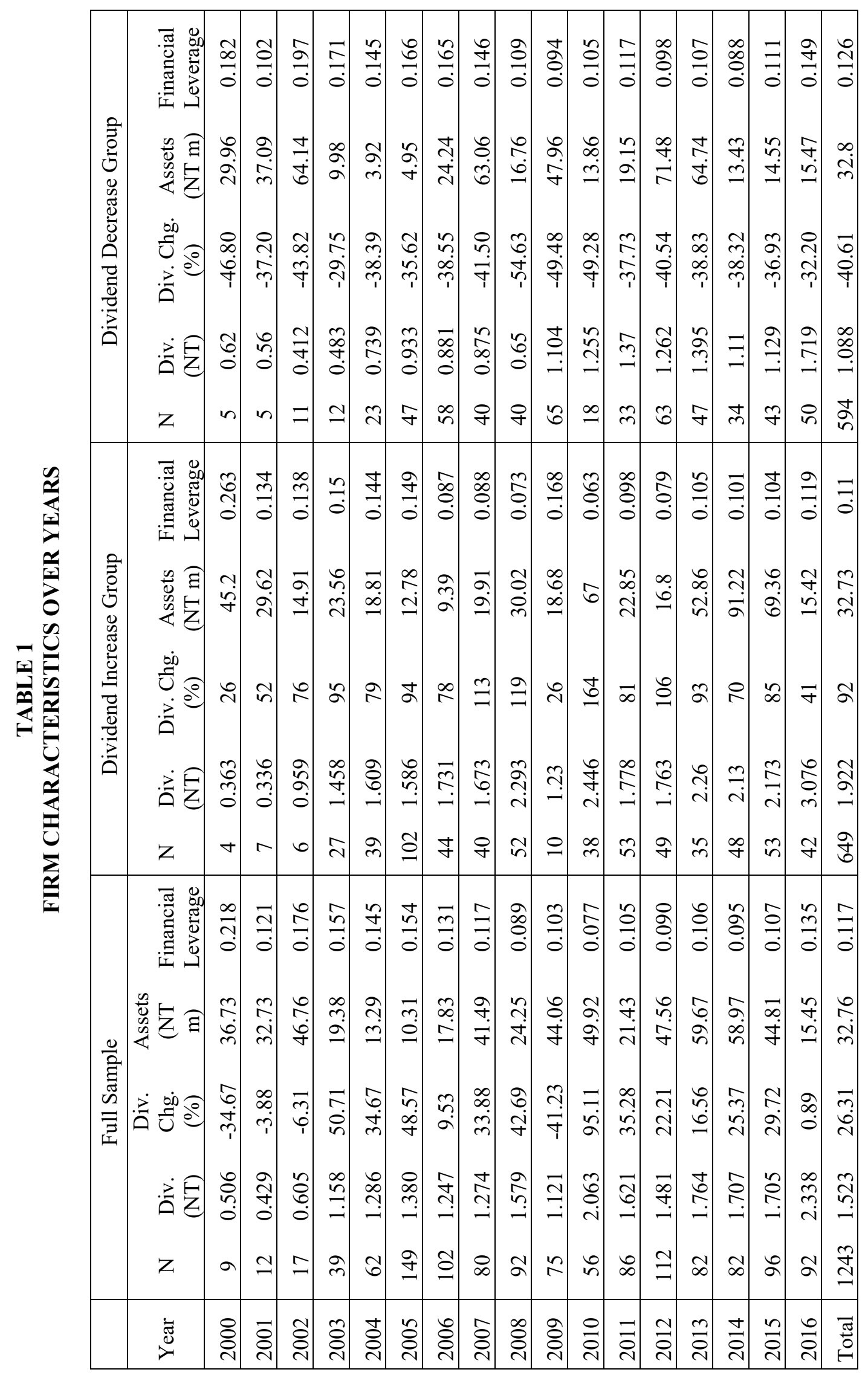




\section{Bond Price and Abnormal Performance Measures}

As there is less trading in common corporate bonds in Taiwan, we restrict our sample to convertible bonds, and require that bonds: (1) be denominated in NT dollars; (2) mature in 50 years or less; (3) be rated by TCRI, and (4) neither be in default nor have a tender offer outstanding. Since price changes of short maturity debts are small unless defaults are imminent, we only include bonds and notes with at least one year to maturity.

Some of the bonds in this sample are rarely traded. To obtain a workable sample, we further require that a bond must trade at least 100 times in 100 days, and the sample's day returns are calculable for at least 10 days over this period.

Table 2 demonstrates descriptive statistics of bonds held by the sample firms, including bond's maturity, rating, investment level, and secured level. Since most of Taiwan's bonds do not have Moody's or S\&P ratings, nor domestic ratings, we used TCRI ratings to calculate bond level. TCRI ratings are evaluations of credit risks from TEJ. These ratings score from 1 to 9 embodying risk level of companies. Scores 1 to 4 signify that the risk is low; scores $5 \& 6$ indicate an average risk, and scores 7 to 9 refer to a high risk. We set bonds with scores of 1 to 4 within investment level equal 1 and 0 otherwise. Secured dummy equals 1 if a bond is secured by the issuer's pledge of a specific asset and 0 otherwise. Almost $25 \%$ of our sample is of non-investment level and non-secured level. The means of the sample's TCRI rating goes to 5, which explains why Taiwan companies choose to issue convertible bonds rather than normal bonds. Issuing convertible bonds is a means for a company to minimize negative investor interpretation of its corporate actions. 




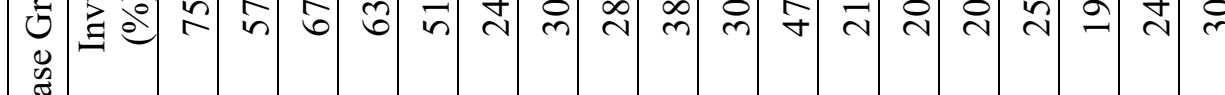

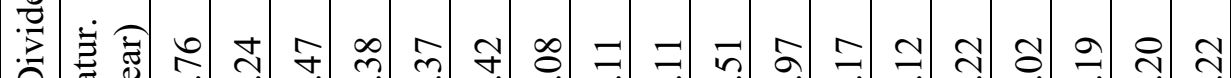

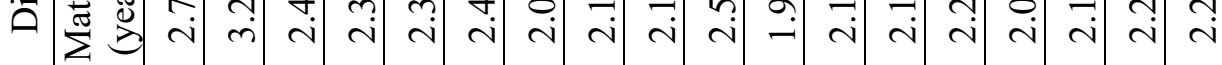
Z $+\sim 6$ స

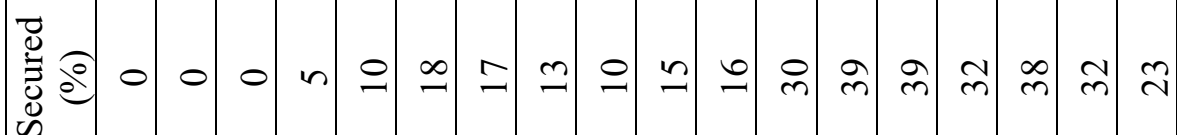
¿̇ं $\frac{0}{2}$

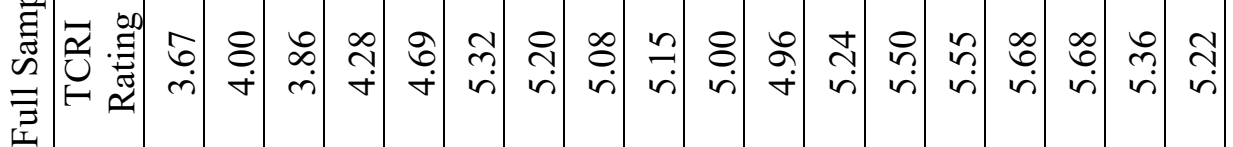

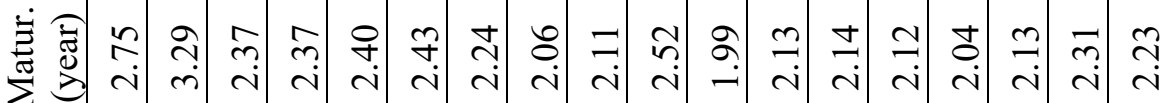
z $\sigma$ ป 若 


\section{EMPIRICAL RESULTS}

\section{Univariate Analysis of Bond and Stock Price Responses to Dividend Announcements}

Woolridge (1983) states that the impact of dividend decisions on security values is different in the presence of information asymmetries. The presumption here is that managers convey their expectations to the market through financial signals. Signaling and wealth transfer effects of dividend decisions are not necessarily mutually exclusive. All else being equal, a dividend increase (decrease) will result in an increase (decrease) in leverage. The leverage alteration in this case tends to be rather small. Nonetheless, a leverage change can cause wealth transfers among security holders in the absence of adequate rules, as well as signal information to investors in markets with less than perfect information.

TABLE 3

SECURITY VALUES AND UNEXPECTED DIVIDEND CHANGES: WEALTH TRANSFER AND SIGNALING

\begin{tabular}{|l|c|c|c|c|}
\hline & \multicolumn{2}{|c|}{ Positive Dividend Change } & \multicolumn{2}{c|}{ Negative Dividend Change } \\
\hline & Wealth Transfer & Signaling & Wealth Transfer & Signaling \\
\hline Common Stock & + & + & - & - \\
\hline Preferred Stock & - & + & + & - \\
\hline Debt & - & + & + & - \\
\hline
\end{tabular}

Data source: Woolridge (1983)

If the signaling hypothesis holds, dividend announcements should have the same impact on stockholders and bondholders. For instance, an announcement of increased dividends signals an optimal cash flow in the future which can also guarantee the timely payment of principal and interest for bonds. Thus, both bond and stock markets will react positively (negatively) to dividend increases (decreases), and this supports the signaling hypothesis. Accordingly, event window CARs of bond and stock prices should be positive (negative) surrounding the announcement of dividend increases (decreases).

If the wealth transfer hypothesis holds, dividend announcements should impact stockholders and bondholders differently. An announcement of increased (decreased) dividends predicts more (less) dividend payments in the future. This announcement causes a positive (negative) reaction in the stock market. On the other hand, it indicates that fewer (more) financial resources are available for future principal and interest payments, which will increase (decrease) default risks on bonds. An increased (decreased) default risk will harm (benefit) the interest of firms' bondholders and lead to a negative (positive) reaction in the bond market. Therefore, event window CARs in bond markets should be negative (positive), surrounding the announcement of dividend increases (decreases). In contrast, CARs over the window in stock markets should be positive (negative), surrounding the announcement of dividend increases (decreases).

Table 4 reports average bond CARs for the full sample of announced dividend increases and decreases in different time frames. For each event window, a t-statistic was used in cross-sectional standard error of bond CARs. For the full sample, dividend increase or decrease panels have a positive and significant effect on bond prices before the event date, especially over the window from day -60 to day -30 . Moreover, the dividend increase announcements have a mean bond CAR of 0.2 percent over the window between day -1 and day +1 while the dividend decrease announcements have a mean bond CAR of -0.09 percent over the same window. This serves as evidence for market efficiency that the announcement event will affect the investor's decisions. Furthermore, the dividend increase announcements have significant negative bond CARs after the announcement, supporting the wealth transfer hypothesis.

We compare three different sets of time frames (2000-2006, 2007-2009, and after 2009) and find that the mean bond CARs in 2000-2006 and 2007-2009 are much higher than the mean bond CARs after 2009 in both increase and decrease groups. It is especially significant in the 2000-2007 frame. We also observe 
that investors are more profitable before the global financial crisis. For that reason, we assume that there was more insider trading before 2009. Also, during the financial crisis, the significance of bond CARs after announcements become lower for the dividend increase group which might be caused by unstable financial environments due to the crisis.

TABLE 4

\section{BOND MARKET RESPONSES TO DIVIDEND ANNOUNCEMENTS SEGMENTED BY PERIODS}

\begin{tabular}{|c|c|c|c|c|c|c|}
\hline \multirow{2}{*}{$\begin{array}{l}\text { Event Window } \\
\text { (days) }\end{array}$} & \multicolumn{3}{|c|}{ Dividend Increase Group } & \multicolumn{3}{|c|}{ Dividend Decrease Group } \\
\hline & $\mathrm{N}$ & Mean CAR & $p$-value & $\mathrm{N}$ & Mean CAR & $p$-value \\
\hline \multicolumn{7}{|c|}{ Full Sample Period: $2000-2016$} \\
\hline$(-90,-60)$ & 335 & $0.69 \%$ & 0.1057 & 315 & $1.74 \%$ & $<.0001 * * *$ \\
\hline$(-60,-30)$ & 335 & $2.09 \%$ & $<.0001 * * *$ & 315 & $2.88 \%$ & $<.0001 * * *$ \\
\hline$(-30,-5)$ & 335 & $0.75 \%$ & $0.0525 *$ & 315 & $1.22 \%$ & $0.0002 * * *$ \\
\hline$(-5,5)$ & 335 & $0.18 \%$ & 0.4118 & 315 & $0.22 \%$ & 0.297 \\
\hline$(-1,1)$ & 335 & $0.20 \%$ & 0.1334 & 315 & $-0.09 \%$ & 0.4335 \\
\hline$(2,30)$ & 335 & $-1.18 \%$ & $0.0102 * *$ & 315 & $0.68 \%$ & $0.0933^{*}$ \\
\hline$(30,60)$ & 335 & $-1.93 \%$ & $<.0001 * * *$ & 315 & $0.35 \%$ & 0.337 \\
\hline \multicolumn{7}{|c|}{ Sub-Sample Period: 2000-2006 } \\
\hline$(-90,-60)$ & 100 & $1.28 \%$ & $0.0972 *$ & 72 & $2.48 \%$ & $0.0038 * * *$ \\
\hline$(-60,-30)$ & 100 & $3.69 \%$ & $0.0009 * * *$ & 72 & $3.93 \%$ & $0.0003 * * *$ \\
\hline$(-30,-5)$ & 100 & $0.30 \%$ & 0.719 & 72 & $1.89 \%$ & $0.0248 * *$ \\
\hline$(-5,5)$ & 100 & $-0.23 \%$ & 0.6378 & 72 & $0.34 \%$ & 0.4412 \\
\hline$(-1,1)$ & 100 & $0.38 \%$ & 0.1164 & 72 & $0.27 \%$ & 0.3085 \\
\hline$(2,30)$ & 100 & $-2.25 \%$ & $0.029 * *$ & 72 & $1.56 \%$ & 0.1605 \\
\hline$(30,60)$ & 100 & $-3.44 \%$ & $<.0001 * * *$ & 72 & $0.72 \%$ & 0.3485 \\
\hline \multicolumn{7}{|c|}{ Sub-Sample Period: 2007-2009 } \\
\hline$(-90,-60)$ & 50 & $0.08 \%$ & 0.9642 & 88 & $3.76 \%$ & $<.0001 * * *$ \\
\hline$(-60,-30)$ & 50 & $1.74 \%$ & 0.1906 & 88 & $3.55 \%$ & $<.0001 * * *$ \\
\hline$(-30,-5)$ & 50 & $1.45 \%$ & 0.1279 & 88 & $2.29 \%$ & $0.0001 * * *$ \\
\hline$(-5,5)$ & 50 & $0.86 \%$ & 0.2189 & 88 & $0.51 \%$ & 0.1195 \\
\hline$(-1,1)$ & 50 & $-0.11 \%$ & 0.7201 & 88 & $-0.24 \%$ & 0.2865 \\
\hline$(2,30)$ & 50 & $0.21 \%$ & 0.868 & 88 & $2.02 \%$ & $0.0206^{* *}$ \\
\hline$(30,60)$ & 50 & $0.14 \%$ & 0.9125 & 88 & $1.62 \%$ & $0.0797^{*}$ \\
\hline \multicolumn{7}{|c|}{ Sub-Sample Period: 2009-20016 } \\
\hline$(-90,-60)$ & 185 & $0.54 \%$ & 0.2039 & 155 & $0.27 \%$ & 0.4536 \\
\hline$(-60,-30)$ & 185 & $1.32 \%$ & $0.0032 * * *$ & 155 & $2.02 \%$ & $<.0001 * * *$ \\
\hline$(-30,-5)$ & 185 & $0.80 \%$ & $0.0927^{*}$ & 155 & $0.30 \%$ & 0.4885 \\
\hline$(-5,5)$ & 185 & $0.22 \%$ & 0.3577 & 155 & $0.01 \%$ & 0.9833 \\
\hline$(-1,1)$ & 185 & $0.18 \%$ & 0.314 & 155 & $-0.17 \%$ & 0.2679 \\
\hline$(2,30)$ & 185 & $-0.98 \%$ & $0.0592 *$ & 155 & $-0.48 \%$ & 0.243 \\
\hline$(30,60)$ & 185 & $-1.67 \%$ & $0.0003 * * *$ & 155 & $-0.54 \%$ & 0.1573 \\
\hline
\end{tabular}


Table 5 shows the average bond CARs for the full sample of announced dividend increases and decreases at different investment levels. In this table, there exists a positive and significant effect during the period $[-60,-30]$. The bond CARs for speculative level are higher than those of investment level, which is consistent with Bessembinder et al., (2009). In period [-1, 1], the CAR is positive within the dividend increase group. It is especially significant at the investment level. Hence, the investment level dividend group supports the signaling hypothesis.

TABLE 5

BOND MARKET RESPONSES TO DIVIDEND ANNOUNCEMENTS SEGMENTED BY RATING GRADES

\begin{tabular}{|c|c|c|c|c|c|c|}
\hline \multicolumn{7}{|c|}{ Dividend Decrease Group } \\
\hline \multirow[b]{2}{*}{ Event Window } & \multicolumn{3}{|c|}{ Speculative } & \multicolumn{3}{|c|}{ Investment } \\
\hline & $\mathrm{N}$ & Mean CAR & $p$-value & $\mathrm{N}$ & Mean CAR & $p$-value \\
\hline$(-90,-60)$ & 208 & $1.60 \%$ & $0.0006 * * *$ & 108 & $2.02 \%$ & $0.0011 * * *$ \\
\hline$(-60,-30)$ & 208 & $3.32 \%$ & $<.0001 * * *$ & 108 & $2.03 \%$ & $<.0001 * * *$ \\
\hline$(-30,-5)$ & 208 & $1.42 \%$ & $0.0018 * * *$ & 108 & $0.83 \%$ & 0.0459 \\
\hline$(-5,5)$ & 208 & $0.28 \%$ & 0.3416 & 108 & $0.12 \%$ & 0.6709 \\
\hline$(-1,1)$ & 208 & $-0.13 \%$ & 0.416 & 108 & $-0.01 \%$ & 0.9407 \\
\hline$(2,30)$ & 208 & $0.71 \%$ & 0.2072 & 108 & $0.64 \%$ & 0.2062 \\
\hline$(30,60)$ & 208 & $-0.02 \%$ & 0.9601 & 108 & $1.08 \%$ & 0.0365 \\
\hline \multicolumn{7}{|c|}{ Dividend Increase Group } \\
\hline & \multicolumn{3}{|c|}{ Speculative } & \multicolumn{3}{|c|}{ Investment } \\
\hline$(-90,-60)$ & 210 & $1.05 \%$ & $0.0552 *$ & 126 & $0.09 \%$ & 0.8938 \\
\hline$(-60,-30)$ & 210 & $2.18 \%$ & $0.0005^{* * *}$ & 126 & $1.94 \%$ & $0.0028 * * *$ \\
\hline$(-30,-5)$ & 210 & $1.29 \%$ & $0.0144 * *$ & 126 & $-0.17 \%$ & 0.7557 \\
\hline$(-5,5)$ & 210 & $0.09 \%$ & 0.7771 & 126 & $0.34 \%$ & 0.196 \\
\hline$(-1,1)$ & 210 & $0.12 \%$ & 0.5176 & 126 & $0.32 \%$ & $0.0482 * *$ \\
\hline$(2,30)$ & 210 & $-1.02 \%$ & 0.1063 & 126 & $-1.45 \%$ & $0.0207 * *$ \\
\hline$(30,60)$ & 210 & $-2.44 \%$ & $<.0001 * * *$ & 126 & $-1.07 \%$ & 0.1073 \\
\hline
\end{tabular}

Table 6 reports the stock market reactions to dividend increase and decrease announcements made the firms that hold bonds. Consistent with prior studies, we find that the stock market reacts positively to dividend increases but negatively to dividend decreases on the window from day -1 to +1 . The evidence of positive bond and stock event window returns surrounding the announcement of increased dividends supports the signaling hypothesis, which entails that dividend increase announcements should result in a positive change in both bond and stock prices.

We also find that the mean stock CARs in the period of 2007-2009 is almost negative and lower than those of the other two periods. As previously discussed, this might result from the unstable financial environment caused by the crisis. Focusing on period $[-1,1]$, we detect significantly negative stock CARs in the dividend increase group during the period of 2007-2009, which proves that the dividend increase group does not support the signaling hypothesis. 
TABLE 6

STOCK MARKET RESPONSES TO DIVIDEND ANNOUNCEMENTS

\begin{tabular}{|c|c|c|c|c|c|c|}
\hline Event window & $\mathrm{N}$ & Mean CAR & $p$-value & $\mathrm{N}$ & Mean CAR & $p$-value \\
\hline Full Sample & \multicolumn{3}{|c|}{ Dividend Increase Group } & \multicolumn{3}{|c|}{ Dividend Decrease Group } \\
\hline$(-90,-60)$ & 320 & $0.16 \%$ & 0.8074 & 393 & $-0.48 \%$ & 0.4309 \\
\hline$(-60,-30)$ & 320 & $0.55 \%$ & 0.435 & 393 & $2.30 \%$ & $0.0003 * * *$ \\
\hline$(-30,-5)$ & 320 & $-0.27 \%$ & 0.6312 & 393 & $1.26 \%$ & $0.0207 * *$ \\
\hline$(-5,5)$ & 320 & $-0.11 \%$ & 0.7466 & 393 & $0.02 \%$ & 0.9606 \\
\hline$(-1,1)$ & 320 & $0.37 \%$ & $0.0414 * *$ & 393 & $-0.09 \%$ & 0.6261 \\
\hline$(2,30)$ & 320 & $-2.50 \%$ & $<.0001 * * *$ & 393 & $-1.20 \%$ & $0.0464 * *$ \\
\hline$(30,60)$ & 320 & $-3.34 \%$ & $<.0001 * * *$ & 393 & $-0.31 \%$ & 0.543 \\
\hline \multicolumn{7}{|l|}{$2000-2006$} \\
\hline$(-90,-60)$ & 124 & $1.00 \%$ & 0.322 & 90 & $1.47 \%$ & 0.2832 \\
\hline$(-60,-30)$ & 124 & $1.16 \%$ & 0.3673 & 90 & $1.66 \%$ & 0.3213 \\
\hline$(-30,-5)$ & 124 & $0.08 \%$ & 0.9343 & 90 & $0.87 \%$ & 0.5096 \\
\hline$(-5,5)$ & 124 & $-0.12 \%$ & 0.8296 & 90 & $0.01 \%$ & 0.9865 \\
\hline$(-1,1)$ & 124 & $0.76 \%$ & $0.0093 * * *$ & 90 & $-0.27 \%$ & 0.497 \\
\hline$(2,30)$ & 124 & $-2.77 \%$ & $0.0102 * *$ & 90 & $0.06 \%$ & 0.97 \\
\hline$(30,60)$ & 124 & $-4.23 \%$ & $<.0001$ & 90 & $0.31 \%$ & 0.7745 \\
\hline \multicolumn{7}{|l|}{ 2007-2009 } \\
\hline$(-90,-60)$ & 60 & $-1.51 \%$ & 0.3799 & 103 & $-1.55 \%$ & 0.3207 \\
\hline$(-60,-30)$ & 60 & $-1.46 \%$ & 0.3571 & 103 & $2.84 \%$ & $0.0382 * *$ \\
\hline$(-30,-5)$ & 60 & $1.14 \%$ & 0.4091 & 103 & $4.34 \%$ & $0.0021 * * *$ \\
\hline$(-5,5)$ & 60 & $0.37 \%$ & 0.6801 & 103 & $0.26 \%$ & 0.761 \\
\hline$(-1,1)$ & 60 & $-0.57 \%$ & 0.1713 & 103 & $-0.29 \%$ & 0.507 \\
\hline$(2,30)$ & 60 & $-0.28 \%$ & 0.8224 & 103 & $-0.13 \%$ & 0.9354 \\
\hline$(30,60)$ & 60 & $-1.49 \%$ & 0.2248 & 103 & $0.52 \%$ & 0.6793 \\
\hline \multicolumn{7}{|l|}{ After 2009} \\
\hline$(-90,-60)$ & 226 & $0.65 \%$ & 0.3235 & 200 & $-0.79 \%$ & 0.215 \\
\hline$(-60,-30)$ & 226 & $0.40 \%$ & 0.5408 & 200 & $2.31 \%$ & 0.0012 \\
\hline$(-30,-5)$ & 226 & $-0.81 \%$ & 0.1058 & 200 & $-0.15 \%$ & 0.766 \\
\hline$(-5,5)$ & 226 & $-0.23 \%$ & 0.515 & 200 & $-0.11 \%$ & 0.8002 \\
\hline$(-1,1)$ & 226 & $0.39 \%$ & $0.0294 * *$ & 200 & $0.10 \%$ & 0.6423 \\
\hline$(2,30)$ & 226 & $-2.94 \%$ & $<.0001 * * *$ & 200 & $-2.33 \%$ & $<.0001 * * *$ \\
\hline$(30,60)$ & 226 & $-2.87 \%$ & $<.0001 * * *$ & 200 & $-1.02 \%$ & 0.0844 \\
\hline
\end{tabular}

Multivariate Analysis of the Determinants of Bond Price Responses to Dividend Announcements

In this section, we aim to detect the factors influencing bond CARs, especially in the period [-60, -30]. Building on King's (2009) study, we examine whether insider trading exists through presence of abnormal 
returns. We also test the signaling and wealth transfer hypotheses in the periods $[-1,-1],[2,30]$, and $[30$, $60]$ within dividend increase group.

Besides dividend changes, many factors may also influence bond price responses. Bessembinder et al. (2009) report higher bond abnormal return variance for speculative grade than for investment grade bonds. Moreover, prices are more variable for long-term bonds than short-term notes.

Handjinicolaou and Kalay (1984) notice that bondholders' losses surrounding dividend announcements are positively correlated with firm financial leverage. Maxwell and Stephens (2003) prove that the loss of bondholders surrounding stock repurchases is a function of the firm's debt rating. When a firm faces default risks, the price of bonds with longer maturity may drop drastically than shorter maturity bonds. Therefore, the bond market reaction to dividend announcements may vary with bond seniority, rating, maturity, and the firm's financial leverage ratio. Jason (2014) also suggested that some financial variables, such as firm size and financial leverage, may influence bond price responses.

Table 7 reports multivariate regression results of the full sample as well as dividend increase and decrease groups separately. The dependent variable is the bond CARs over the event window $[-60,-30]$ and the key independent variable is the dividend changes. The control variables can be categorized at three levels. First, we observe how the characteristics of bonds (such as bond seniority, bond rating, and bond maturity) affect bond prices. Time control (Prior 2009) is also included because we find significant bond CARs after the financial crisis. The results are presented in Models 1, 4 and 7. Secured level is an indicator variable with a value of one if a bond is secured by the issuer's pledge of a specific asset. Bond rating, denoted as Invest., equals one if the TCRI rating belongs to the category of investment-grade rating. Maturity denotes the natural logarithm of years remaining for bonds. Prior 2009 is one if an event occurred before 2009. Second, we take firm financial variables into consideration and add financial leverage and firm size into the regression. Results are presented in Models 2, 5 and 8. Financial leverage is defined as the ratio of book value of long-term debt over the book value of the total assets of the firm. Firm size is measured as the logarithm of the debt and equity of the firm. Third, we factored in directors and supervisors' stock holdings and management stock holdings. Results are presented in Models 3, 6 and 9. 


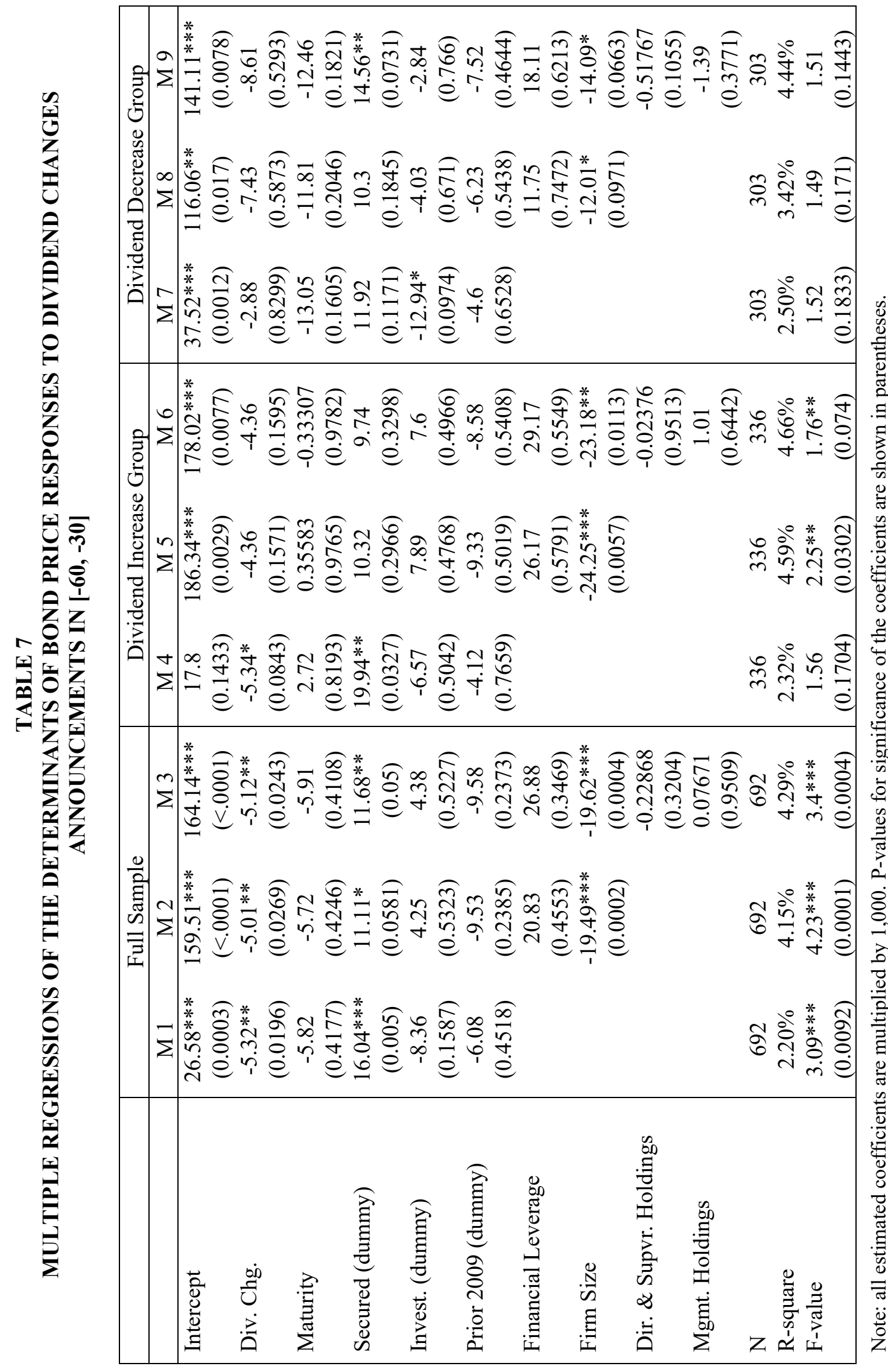

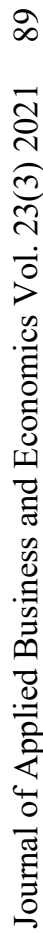


In Models 1-3, abnormal returns on bonds are negatively affected by dividend changes, significantly in all models. In Models 4 to 6, dividend changes are negatively associated with bond CARs at mixed significance levels. These results imply that the bonds are facing a price-going-down pressure before the firms with the bond outstanding make a dividend increase announcement. During the period from -60 day to -30 day, investors would buy bonds at lower price when they predict dividend increases. We suspected that some investors take advantage of the information and buy first, so that they can make profit in the future when the news is public. CARs are negatively significant with firm sizes. This seems reasonable as bigger companies have more advanced supervision, and that helps to minimize insider trading. In Models 7 to 9, CARs are negatively significant, with firm sizes. And in Models 4 and 9, the secured dummy is positive and significant which implies that secured bonds have higher CARs during the period from -60 day to -30 day. In Models 3, 6 and 9, although we find abnormal returns before the event day, we cannot prove that CARs are directly and significantly related to director and supervisor holding or management holdings. Therefore, we cannot conclude that insider trading exists here.

In the next section, we will analyze the signaling and wealth transfer hypotheses in the period $[-1,-1]$. Same factors from Table 7 are inputted to run multiple regressions again. Results are presented in Table 8. 


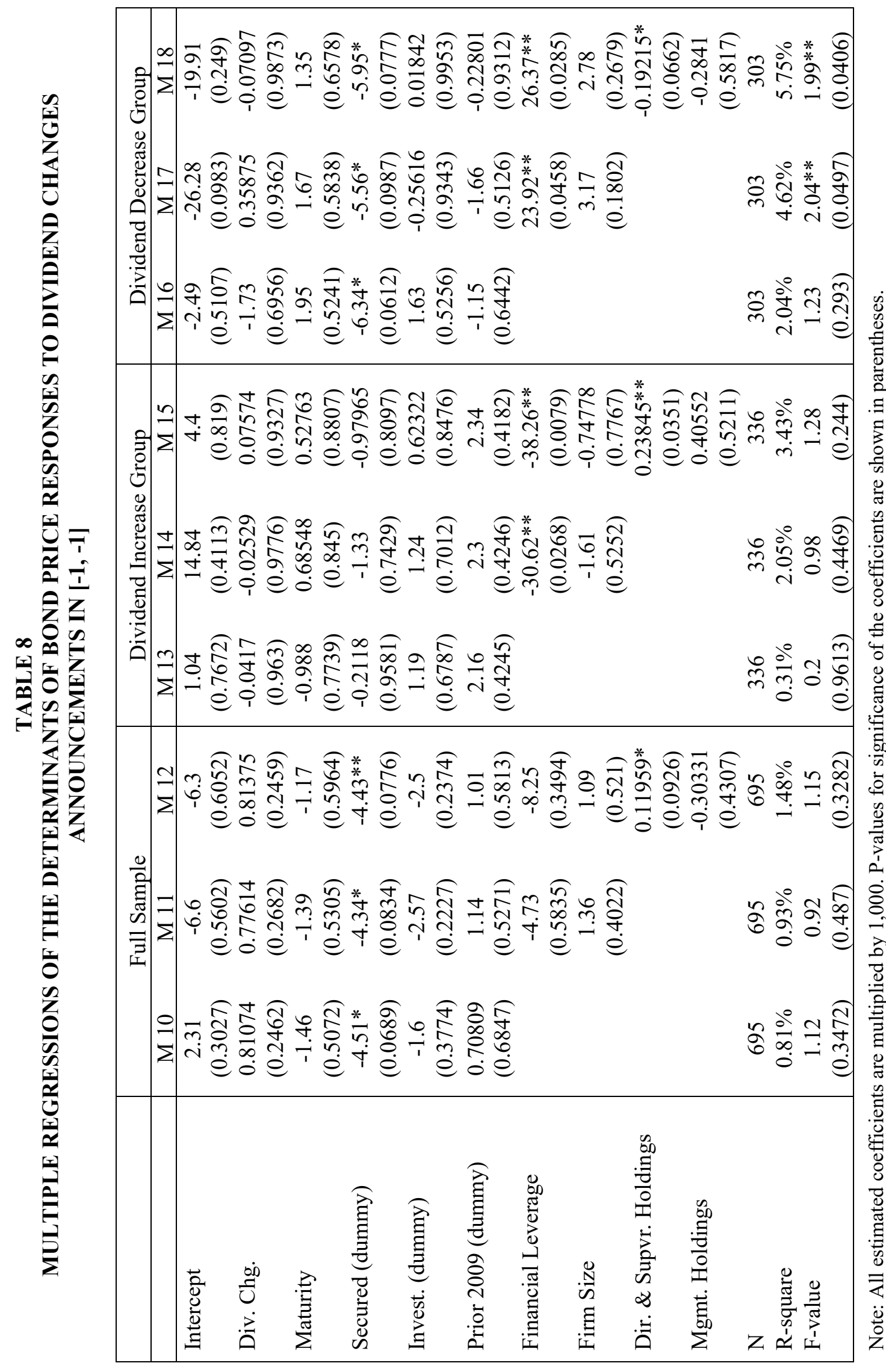

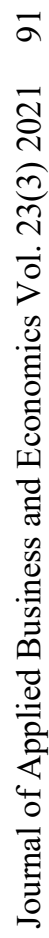


Table 8 documents multivariate regression results of the full sample as well as the dividend increase and decrease groups separately. From Models 10 to 18, neither the signaling hypothesis nor wealth transfer hypothesis holds for the group of dividend announcements by the insignificant coefficients for dividend changes. For that reason, it seems that Taiwan's bond market is inefficient. Some explanations are possible. First, trading volume of Taiwan bonds is very low. There are not many investors interested in this market, thus dividend decreasing or increasing will not entail large trading. Second, we find insider trading during the period $[-60,-30]$ that inside investors buy or sell bonds before the event day and dividend changes would affect CARs. According to the previous research, the signaling and wealth transfer effects in bond prices tend to offset each other. Additionally, financial leverage is significant in both dividend increase and decrease groups. This result, however, contradicts with the prediction on the signaling hypothesis. The factor of directors' and supervisors' holdings is significantly positive within the dividend increase group and negative in the decrease group. Therefore, when insider holdings are higher, CARs will be higher for the dividend increase group and lower for the decrease group. We even observe this many more days after the event day to make sure of this phenomenon in Taiwan's bond market.

In Table 9, we run multiple regressions for the dividend increase group in the periods $[2,30]$ and $[30$, 60] to scrutinize the influence of the global financial crisis. The time control changes to an indicator of During Crisis, which is defined as one if the event occurred during 2007-2009. Results are presented in Table 9, where Models 19 and 20 are for the period [2, 30], and Models 21 and 22 are for the period [30, 60]. In Models 19 and 20, dividend changes are negatively significant with CARs, which supports the wealth transfer hypothesis. We suspect that an unidentified event affected the market and the wealth transfer effect as stock CARs are significantly negative. Investment grade is negatively significant with CARs, which also supports the wealth transfer hypothesis. In Models 21 and 22, dividend changes are not significant so we cannot safely conclude that it supports the wealth transfer. However, CARs are significant during the 2007-2009 period.

TABLE 9

MULTIPLE REGRESSIONS OF THE DETERMINANTS OF BOND PRICE RESPONSES TO DIVIDEND CHANGES ANNOUNCEMENTS IN $[2,30]$ and $[30,60]$

\begin{tabular}{|l|cc|cc|}
\hline & M 19 & M 20 & M 21 & M 22 \\
\hline Intercept & -13.06 & -41.64 & $-22.82^{* *}$ & $-100.78^{* *}$ \\
Div. Chg. & $(0.2701)$ & $(0.4815)$ & $(0.0293)$ & $(0.0537)$ \\
& $-7.95^{* *}$ & $-8.02^{* *}$ & -0.88856 & -1.21 \\
Maturity & $(0.0113)$ & $(0.0109)$ & $(0.7469)$ & $(0.6602)$ \\
& 3.51 & 0.3699 & -5.26 & -5.42 \\
Secured (dummy) & $(0.7692)$ & $(0.976)$ & $(0.6184)$ & $(0.6172)$ \\
Invest. (dummy) & -2.81 & -3.23 & 0.74016 & 2.82 \\
& $(0.7776)$ & $(0.7707)$ & $(0.9516)$ & $(0.8186)$ \\
During Crisis & 21.54 & $23.83 *$ & 12.46 & 6.6 \\
& $(0.1205)$ & $(0.089)$ & $(0.1564)$ & $(0.4992)$ \\
Financial Leverage & 19.58 & $21.54 *$ & $23.67 * *$ & $25.75^{* *}$ \\
Firm Size & $(0.1283)$ & $(0.0976)$ & $(0.0373)$ & $(0.0247)$ \\
& & 56.52 & & 10.91 \\
& & $(0.2382)$ & & $(0.7958)$ \\
\hline
\end{tabular}




\begin{tabular}{|l|cc|cc|}
\hline & & $(0.6877)$ & & $(0.1333)$ \\
$\mathrm{N}$ & 336 & 336 & 336 & 336 \\
R-square & $3.25 \%$ & $3.73 \%$ & $2.12 \%$ & $2.83 \%$ \\
F-value & $2.22 *$ & $1.82 *$ & 1.43 & 1.36 \\
& $(0.0521)$ & $(0.083)$ & $(0.2141)$ & $(0.22)$ \\
\hline
\end{tabular}

Note: All estimated coefficients are multiplied by 1,000. P-values for significance of the coefficients are shown in parentheses.

In Table 10, it is observed that almost all correlation coefficients are positively significant. In other words, Taiwan's market supports the signaling hypothesis. Given these results together with the finding that Taiwan market is inefficient stated previously, we can only conclude that bond returns have positive correlations with stock returns in Taiwan's security market. 


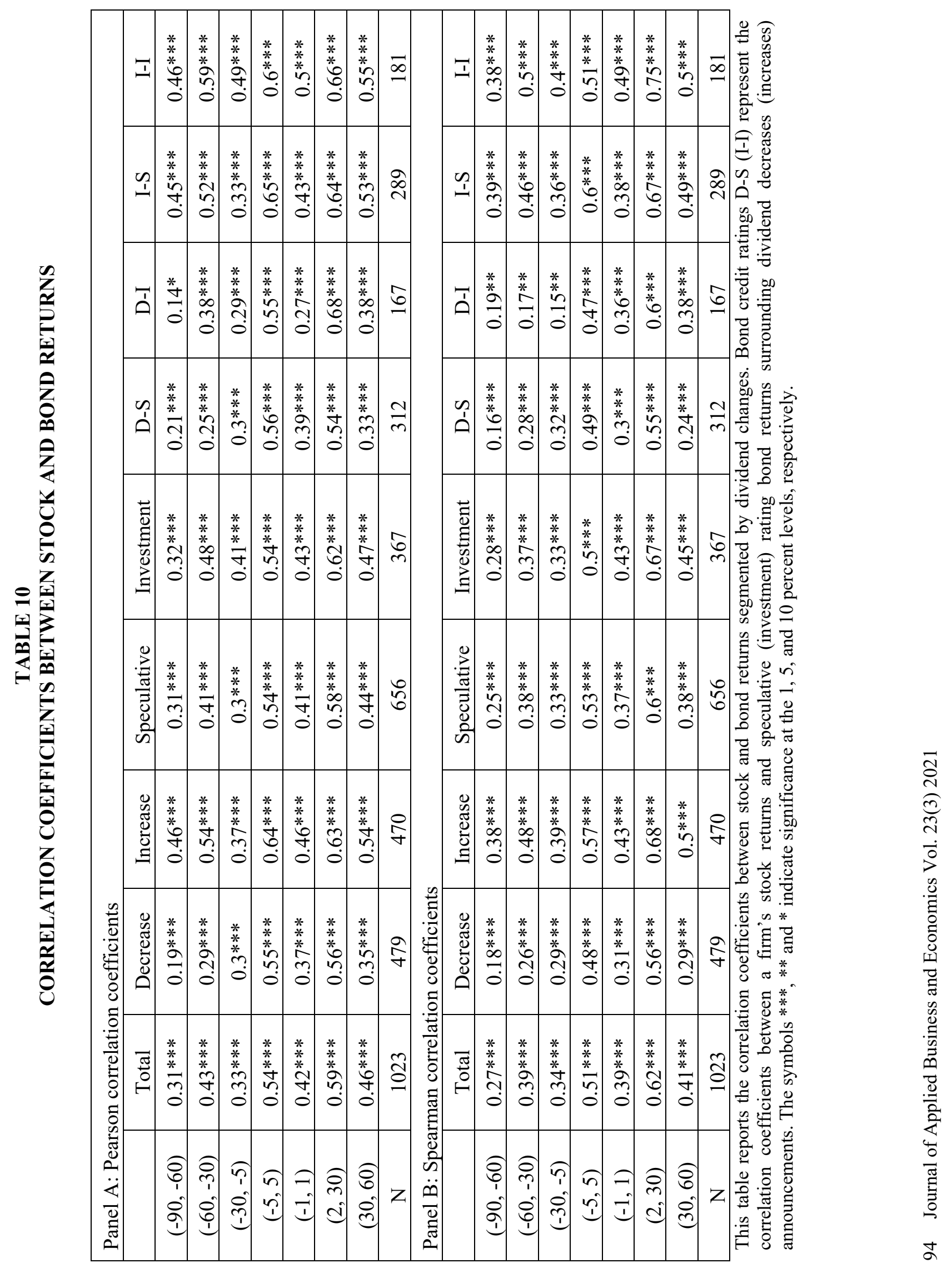




\section{DISCUSSION}

\section{Research Conclusions}

In Taiwan, bonds are a less common financial instruments in capital market, bond data are poor in quality and availability, and studies on bond are mostly scarce. The extant evidence on the impact of dividend announcements on bondholders is limited and mixed in literature. In this paper, we used OTC bond transaction data from TEJ to explore the wealth effects of dividend change announcements on bondholders across the period from January 2000 to December 2016. We find significant abnormal returns during the period from day -60 to day -30 . Also, we find that returns before the global financial crisis is higher than in other periods. We suspect insider trading but do not find concrete evidence to prove it.

We also observe abnormal returns during the period from day -1 to day 1 and find that neither the signaling hypothesis nor wealth transfer hypothesis holds for the group of dividend announcements, given the insignificant coefficients for dividend changes. That may be caused by Taiwan' low bond trading, by insider trading before the event occurred, or by the mixture of signaling and wealth transfer effects. We also observe the periods $[2,30][30,60]$ within the dividend increase group and find some evidence that may support the wealth transfer hypothesis. However, we cannot ensure because some other unidentified factors may also have affected the market.

\section{Research Contributions}

This study is among the first to discuss dividend announcement effect on bonds since the financial crisis and contribute to the literature about the wealth transfer between bondholders and stockholders. We obtain data from TEJ but do not use TEJ's event study system simply because the TEJ system does not support bond calculations. Our result proves that it is worth to build a system for bonds.

In the empirical results, we find some insider trading before the event day. That may be the reason why Taiwan bond trading volume remains low. We use TCRI ratings to replace S\&P or Moody's ratings and notice that investment level has little effect on CARs during the period from day - 60 to -30 and is significant within the dividend increase group. It indicates that TCRI ratings can be used for Taiwan bond market's research.

\section{Research Limitations and Recommendations}

Below are some limitations of our study.

\section{Major Focus on Convertible Bonds (CB)}

While we tried to obtain all data of bond trading form the TEJ, the trading data of common corporate bonds are lacking. Therefore, we could only use CB's trading data for our research. CB's characteristics are more complicated than that of common bonds which may cause an offset between the signaling and wealth transfer effects.

\section{Missing Dividend Announcement Data}

Some dividend announcements data were missing as some companies did not pay dividend on the event days or stopped being operational. This may affect the results.

\section{Market Returns Calculation Method}

In other studies, market returns are calculated by bond ratings. This works for mature bond markets such as U.S. markets. However, Taiwan's bond market is not mature. Therefore, we decide to use Taiex index to replace the market index. Unfortunately, the Taiex index does not include bond prices which may affect accuracy and veracity. We test this out by using Taiwan OTC index to calculate CARs, and get similar results with Taiex index.

Our research could not prove signaling hypothesis or wealth transfer hypothesis during the dividend event. Some previous studies point out that the effect might be mixed. If any researcher wants to discuss 
this situation, he/she can try to find out what environment will enhance the signaling effect or wealth transfer effect (like good corporate governance or performance of company).

\section{REFERENCES}

Adams, J.C., \& Mansi, S.A. (2009). CEO turnover and bondholder wealth. Journal of Banking \& Finance, 33(3), 522-533.

Aharony, J., \& Swary, I. (1980). Quarterly dividend and earnings announcements and stockholders' returns: An empirical analysis. The Journal of Finance, 35(1), 1-12.

Bessembinder, H., Kahle, K.M., Maxwell, W.F., \& Xu, D. (2009). Measuring abnormal bond performance. Review of Financial Studies, 22, 4219-4258.

Bessembinder, H., Panayides, M., \& Venkataraman, K. (2009). Hidden liquidity: An analysis of order exposure strategies in electronic stock markets. Journal of Financial Economics, 94(3), 361-383.

Billet, M.T., \& King, T.D., Mauer, D.C. (2004). Bondholder wealth effects in mergers and acquisition: New Evidence from the 1980s and 1990s. Journal of Finance, 5.

Brown, S.J., \& Warner, J.B. (1985). Using daily stock returns: The case of event studies. Journal of Financial Economics, 14(1), 3-31.

Chang. (1996). Information of Cash dividend, relationship of Tobin's $Q$ and dividend rate. National Chung Cheng University, Taiwan.

Chang. (2010). The comparison of announcement effect on private convertible bond and public convertible bond. National Chengchi University, Taiwan.

Dhillon, U.S., \& Johnson, H. (1994). The effect of dividend changes on stock and bond prices. The Journal of Finance, 49(1), 281-289.

Fama, E.F. (1970). Efficient Capital Markets: A Review of Theory and Empirical Work. The Journal of Finance, pp. 383-417.

Farmer, D., \& Lo, A.W. (1998, November 19-21). Frontiers of Finance: Evolution and Efficient Markets. In A summary of the session presented at the tenth annual symposium on Frontiers of Science.

Galai, D., \& Masulis, R.W. (1976). The option pricing model and the risk factor of stock. Journal of Financial Economics, 3(1-2), 53-81.

Hadi, M.M. (2006). Review of capital market efficiency: Some evidence from Jordanian market. International Research Journal of Finance and Economics, 3, 13-27.

Handjinicolaou, G., \& Kalay, A. (1984). Wealth redistributions or changes in firm value: An analysis of returns to bondholders and stockholders around dividend announcements. Journal of Financial Economics, 13(1), 35-63.

Healy, P.M., \& Palepu, K.G. (1988). Earnings information conveyed by dividend initiations and omissions. Journal of Financial Economics, 21(2), 149-175.

King, M.R. (2009). Prebid Run-Ups Ahead of Canadian Takeovers: How Big Is the Problem? Financial Management, 38(4), 699-726.

Lin, Y-M., \& Pan, C-Y. (1998). The Information Content of Dividend Announcements and Tobin's Q Theory. Journal of Management, 15(4), 587-621.

Liu, A., \& Hsueh, P. (2012). Bond market. Hwa Tai Publishing, Taiwan.

Maxwell, W.F., \& Rao, R.P. (2003). Do Spin-offs Expropriate Wealth from Bondholders? The Journal of Finance, 58(5), 2087-2108.

Maxwell, W.F., \& Stephens, C.P. (2003). The wealth effects of repurchases on bondholders. The Journal of Finance, 58(2), 895-920.

Miller, M.H., \& Modigliani, F. (1961). Dividend policy, growth, and the valuation of shares. The Journal of Business, 34(4), 411-433. Woolridge (1983).

Miller, M.H., \& Rock, K. (1985). Dividend policy under asymmetric information. The Journal of Finance, 40(4), 1031-1051.

Nissim, D., \& Ziv, A. (2001). Dividend changes and future profitability. The Journal of Finance, 56(6), 2111-2133. 
Sharp W.F. (1963). A simplified model for portfolio analysis. Management Science, 9, 277-93. Tsai, H-M. (1994). A Study of the Impact of Stock Dividend on Trading Volume. National Taiwan University, Taiwan.

Turkiela, J. (2014). How Do Dividend Announcements Affect Bondholder and Shareholder Wealth?

Vermaelen, T. (1981). Common stock repurchases and market signalling: An empirical study. Journal of Financial Economics, 9(2), 139-183.

Wang, X.H. (1994). Relation of stock dividend and stock price. National Taiwan University, Taiwan.

Woolridge, J.R. (1983). Dividend changes and security prices. The Journal of Finance, 38(5), 1607-1615.

Yang, L-H. (2013). The announcement effect of convertible bonds in Taiwan Market based on Multifactor pricing models. National Cheng Kung University, Taiwan. 